\title{
Standardization of Hydropriming Duration and its Effect on Physiological Parameters of Spinach (Spinacea oleracea L.)
}

\author{
A. K. Kulsumbi ${ }^{1 *}$, I. M. Sangeeta ${ }^{2}$, N. M. Shakuntala ${ }^{2}$, S. N. Vasudevan ${ }^{3}$ and B. Kisan ${ }^{4}$ \\ ${ }^{1}$ Department of Seed Science and Technology, ${ }^{2}$ Dept. of SST, AC, UASR, ${ }^{3} A D R, Z A R S, V C$ \\ Farm, Mandya, ${ }^{4}$ Dept. of Biotechnology, MARS, UASR, College of Agriculture, University of \\ Agricultural Sciences Raichur, Raichur-584 104, India \\ *Corresponding author
}

\section{A B S T R A C T}

\section{Keywords}

Germination,

Hydropriming,

Mean germination

time, Spinacea

oleracea, Vigour

Article Info

Accepted:

18 July 2020

Available Online:

10 August 2020
Seed germination and subsequent seedling growth define crucial steps for entry into the plant life cycle and proper seed germination is a basic prerequisite for getting a better crop yield. Hence standardization of hydropriming duration in spinach seeds is an important pre-requisite to improve physiological and biochemical parameters, therefore seeds were soaked in different time intervals from 12, 16, 20, 24, 28 and 32 hours. Seeds soaked in water for 24 hours improved seed quality parameters over control, where germination increased to 94.25 per cent in seeds soaked in 24 hours.

\section{Introduction}

Spinach (Spinacia oleracea L.) is an edible flowering plant in the family Amaranthaceae. It was long considered to be in the family Chenopodiaceae, but in 2003, that family was merged into the family Amaranthaceae in the order Caryophyllales. Within the family Amaranthaceae, spinach belongs to subfamily Chenopodioideae. Spinach is most probably a native of central and western Asia region. It was known in China as early as 647 AD. Spinach, swiss chard and garden beet has a chromosome number $2 n=2 x=24$, indicates their close relationship. Leaves of this crop might have been first used in Bengal and hence it is known as Beta vulgaris var. bengalensis. Spinach is one of the most common leafy vegetables of tropical and subtropical regions. The popular spinach growing states include Uttar Pradesh, West Bengal, Maharashtra and Gujarat. However, spinach is not very popular in South India. It is primarily used as pot herb and is a rich Source of vitamin A and $\mathrm{C}$ and also contains appreciable amount of protein, 
calcium and iron. The leaves contain low oxalic acid.

Cultivation of spinach is carried out in cooler regions as it requires about $15-20{ }^{0} \mathrm{C}$ temperature for flowering and seed production. It tolerate frost and high temperature under good irrigation. Under high temperature conditions, early bolting occurs and leaves pass edible stage quickly with poor yield. Though spinach can be grown on a wide range of soils, well fertile, sandy loams soil with good drainage is ideal. Spinach is tolerant to slightly alkaline soils and is highly tolerant to salts also. One of the simple techniques which can improve seedling vigour and establishment is seed priming (Khan et al., 2005). Priming is a pre-sowing seed treatment which permits early DNA replication, increase RNA and protein synthesis, repairs deteriorated seed parts and reduces the leakage of metabolites thus enhances the embryo growth, speed and uniformity of seedlings in field. Primed and dried seeds normally have a more rapid and uniform germination when subsequently rehydrated, especially under adverse environmental conditions.

An important problem encountered in the cultivation of spinach is the poor germination of the seeds when planting is done in extremely warm temperatures, which may delay or inhibit seed germination in the field, reduce uniformity total stand establishment and ultimately reduces the yield. Hence standardization of duration for hydropriming to obtain better crop stand could be an attractive approach in spinach.

\section{Materials and Methods}

The laboratory experiments of present investigation on "Standardization of hydropriming duration and its effect on physiological and biochemical parameters of spinach (Spinacia oleracea L.)" was carried out during 2017-2018 in the Department of Seed Science and Technology, College of Agriculture, University of Agricultural Sciences, Raichur. The details of the materials used and methods adopted during the course of the investigation are presented. Geographically, the station is situated in the North-Eastern dry zone (Zone-2) of Karnataka State at $16^{\circ} 15^{\prime}$ North latitude and $77^{\circ} 20^{\prime}$ East longitude and at an altitude of 389 meter above mean sea level. Fresh seeds of spinach variety "Annapoorna" were obtained from University of Horticultural Sciences, Bagalkot. The Annapoorna is an improved spinach variety with test weight of 10 - $12 \mathrm{~g}$ which matures in 150- 180 days. Spinach crop can be grown on a wide range of soils provided that soils are sufficiently fertilized and well drained.

The experiment was laid out in CRD (Completely Randomized Design) with three replication and the seeds were soaked in water at respective duration with the difference of 4 hours interval and following observations were made.

\section{Results and Discussion}

In the present investigation, the spinach seeds were soaked in water for different durations viz., 12, 16, 20, 24, 28 and 32 hours and the seeds were evaluated for seed quality parameters.

The seeds hydro primed for 24 hours recorded significantly maximum germination $(94.25 \%)$ (Fig. 1a), speed of germination (34.83) (Fig. $1 b)$, root length $(5.79 \mathrm{~cm})$, shoot length $(7.10$ $\mathrm{cm})$, seedling dry weight (19.26 mg), seedling vigour index (1287), germination rate index (3586), peak value of germination (19.26), low mean germination time (2.24) and low electrical conductivity $\left(0.339 \mathrm{dsm}^{-1}\right)$ followed by priming duration of 20 hours $(91.5 \%$, 
$33.59,5.79 \mathrm{~cm}, 7.10 \mathrm{~cm}, 18.46 \mathrm{mg}, 1179$, $3490, \quad 18.47, \quad 2.58$ and $0.446 \mathrm{dSm}^{-1}$, respectively). However, the lowest seed quality parameters were recorded in control
(86.00\%, 28.84, $5.16 \mathrm{~cm}, 6.25 \mathrm{~cm}, 16.03 \mathrm{mg}$, $981,2908,15.59,3.19$ and $0.733 \mathrm{dsm}^{-1}$, respectively) as shown in table 1 .

Table.1 Effect of hydropriming durations on physiological and biochemical parameters of spinach

\begin{tabular}{|c|c|c|c|c|c|c|c|c|}
\hline Treatments & $\begin{array}{l}\text { Root } \\
\text { length } \\
\text { (cm) }\end{array}$ & $\begin{array}{l}\text { Shoot } \\
\text { length } \\
\text { (cm) }\end{array}$ & $\begin{array}{l}\text { Seedling } \\
\text { vigour } \\
\text { index }\end{array}$ & $\begin{array}{l}\text { Seedling dry } \\
\text { weight (mg) }\end{array}$ & $\begin{array}{l}\text { Germina- } \\
\text { tion rate } \\
\text { index }\end{array}$ & $\begin{array}{c}\text { Peak value of } \\
\text { germination }\end{array}$ & $\begin{array}{c}\text { Mean } \\
\text { germination } \\
\text { time }\end{array}$ & $\begin{array}{c}\text { Electrical } \\
\text { conductivity } \\
\left(\mathbf{d S m}^{-1}\right)\end{array}$ \\
\hline $\mathbf{T}_{1^{-}}$Control & 5.16 & 6.25 & 981 & 16.03 & 2908 & 15.59 & 3.19 & 0.733 \\
\hline$T_{2^{-}} 12$ hour & 5.48 & 6.51 & 1058 & 16.84 & 3066 & 16.80 & 2.92 & 0.656 \\
\hline$T_{3^{-}} 16$ hour & 5.53 & 6.85 & 1120 & 17.64 & 3226 & 17.77 & 2.76 & 0.547 \\
\hline$T_{4-20} 20$ hour & 5.79 & 7.10 & 1179 & 18.46 & 3490 & 18.47 & 2.58 & 0.446 \\
\hline$T_{5^{-}} 24$ hour & 6.25 & 7.41 & 1287 & 19.26 & 3586 & 19.26 & 2.24 & 0.339 \\
\hline$T_{6}-28$ hour & 5.68 & 6.87 & 1142 & 18.02 & 3329 & 17.88 & 2.49 & 0.487 \\
\hline$T_{7}-32$ hour & 5.37 & 6.52 & 1037 & 16.54 & 3111 & 17.02 & 2.84 & 0.597 \\
\hline MEAN & 5.54 & 6.78 & 1115 & 17.54 & 3245 & 17.54 & 2.72 & 0.544 \\
\hline S.Em \pm & 0.06 & 0.05 & 12.64 & 0.09 & 50.80 & 0.17 & 0.04 & 0.007 \\
\hline CD @ 1\% & 0.17 & 0.16 & 37.43 & 0.25 & 150.42 & 0.51 & 0.12 & 0.020 \\
\hline
\end{tabular}

Fig.1a \& 1b Effect of hydropriming durations on germination (top) and speed of germination (bottom) of spinach

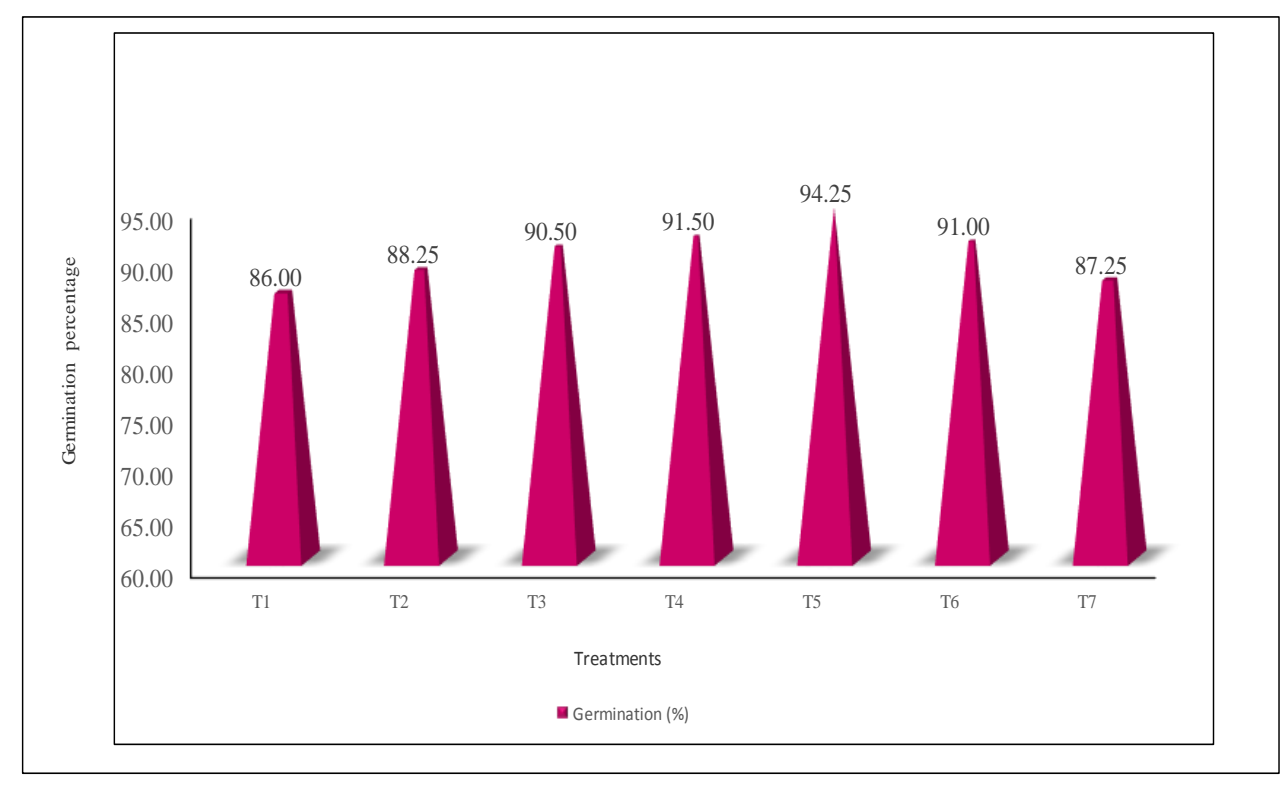


Int.J.Curr.Microbiol.App.Sci (2020) 9(8): 1745-1750

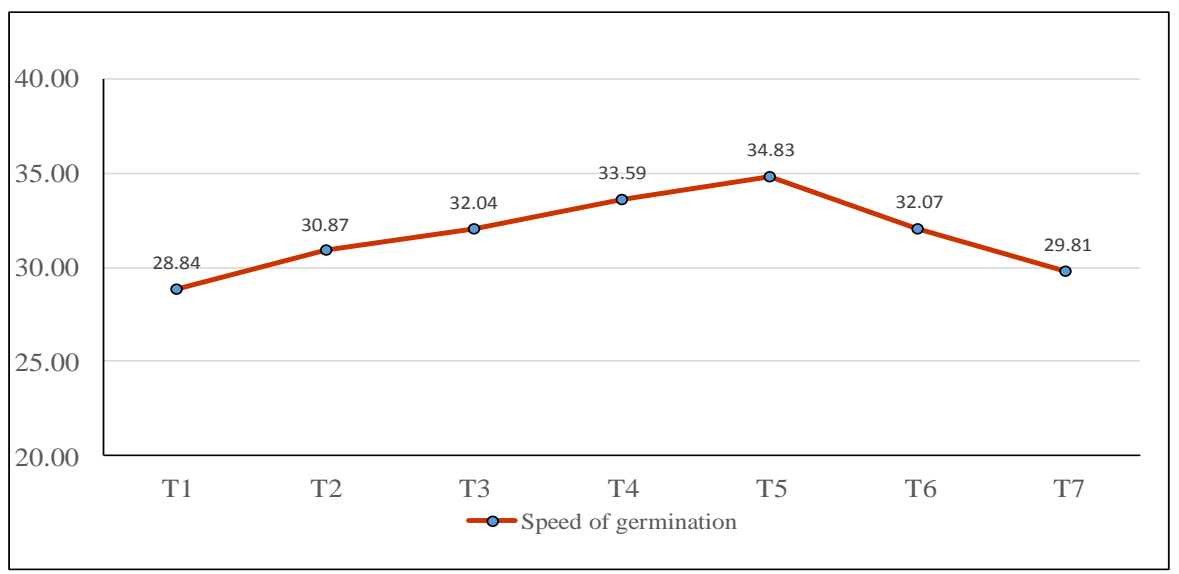

Fig.2a \& 2b Effect of standardization of hydropriming durations on germination (\%) of spinach
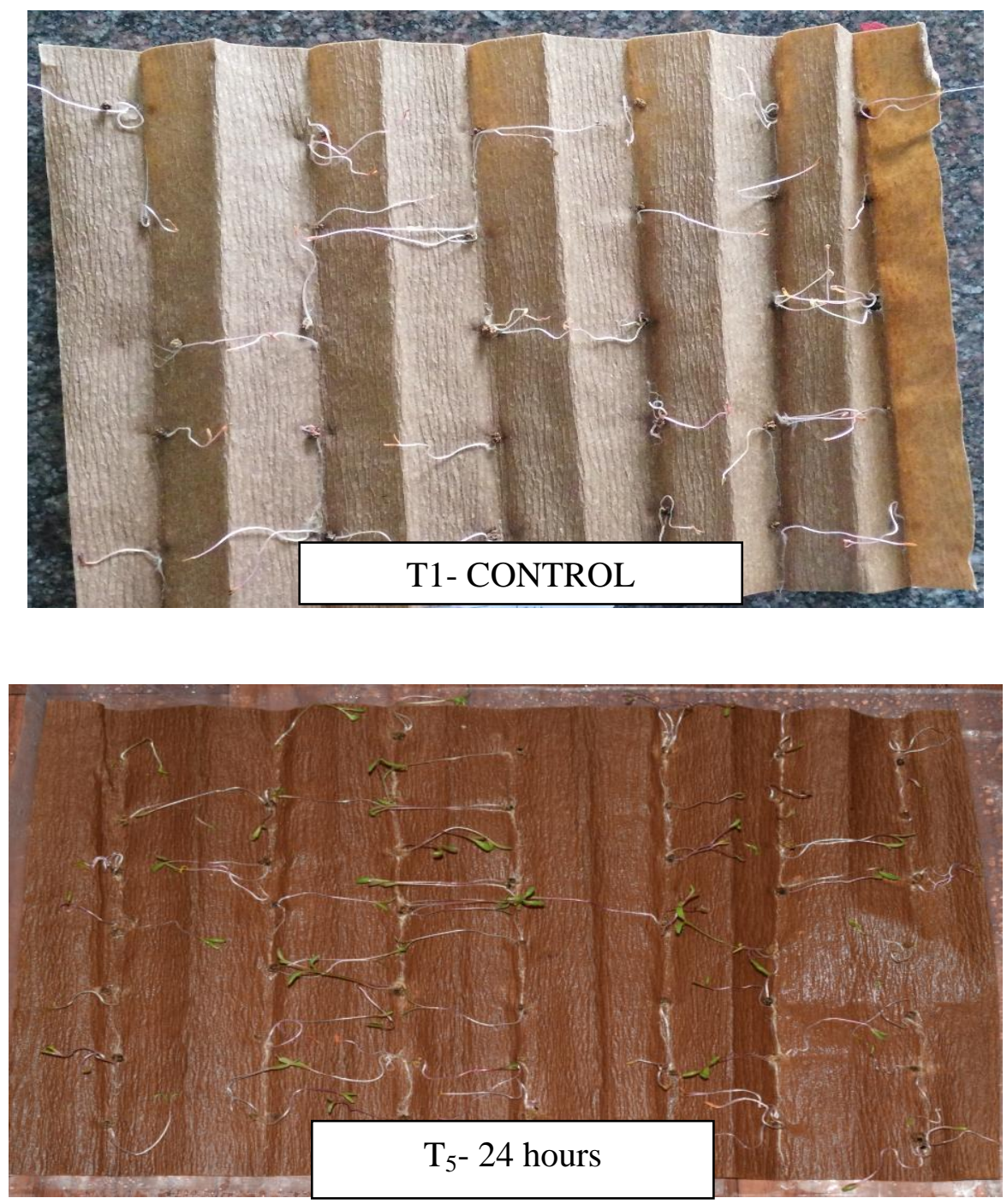
The possible reason for enhanced seed germination and vigour at 24 hours of seed hydro-priming might be due to completion of pre-germinative metabolic processes i.e., activation and synthesis of a number of enzymes and nucleic acids repair and build up, ATP synthesis and the cytoplasmic membrane repair in hydro-primed seed a head start over the non-primed seeds making ready for radical protrusion (Varier et al., 2010) and also during priming, several processes including treated seeds start to develop (Fig $2 b)$. These results are in conformity with Krishnakumar et al., (2008) in sugar beet, Tiwari et al., (2014) in amaranthus, Mohsen et al., (2013), Kamithi et al., (2016), Kaur et al., (2003), Kazem et al., (2012), Abebe (2014) and Rashid et al.(2004) in spinach.

Soaking of spinach seed at both the intervals i.e., below $(<24 \mathrm{~h})$ and above $(>24 \mathrm{~h}) 24$ hours resulted in reduced seed quality parameters (Habib, 2010). The germination of spinach seeds is inhibited by water treatments when soaked for more than 24 hours (28 and $32 \mathrm{~h}$ ) due to membrane disintegrate of seed coat and increased movement of seed leachates resulting in low germination and vigour and also because of higher porosity where water filled pores restricted oxygen access to the fruits. Heydecker et al., (1971) in beetroot reported that the germination was negatively affected by excess water treatment. The seed quality parameters reduced when soaked for less than 24 hours (12, 16 and 20 h) which might be due to incomplete imbibition resulting in reduced activity of hydraulytic enzymes required for reserve mobilization of storage food (Perry and Harrison, 1974). Similar results were given by Orzeszko-Rywka and Podlaski (2003) in palak and Heydecker (1967) in Beta vulgaris.

The seeds were subjected to hydro-priming durations from 0 to 32 hours. These seeds were tested for seed quality parameters to standardize the hydro-priming duration. Among the different hydro-priming durations studied, the seed hydro-primed for 24 hours (T5) duration recorded significantly highest seed quality parameters viz., seed germination (94.25\%), speed of germination (34.83), root length $(6.25 \mathrm{~cm})$, shoot length $(7.41 \mathrm{~cm})$, seedling dry weight $(19.26 \mathrm{mg})$, seedling vigour index (1287), germination rate index (3586), peak value of germination (19.26), mean germination time (2.24) and lowest electrical conductivity (0.339 dsm-1) and was on par with the soaking duration for 20 hours (T4) which recorded $91.50 \%, 33.59,5.79 \mathrm{~cm}$, $7.10 \mathrm{~cm}, 18.46 \mathrm{mg}, 1179,3490,18.47,2.58$ and $0.446 \mathrm{dSm}-1$, respectively. However, significantly minimum seed quality parameters were observed in control (without soaking) (i.e. $86.00 \%, 28.84,5.16 \mathrm{~cm}, 6.25$ $\mathrm{cm}, 16.03 \mathrm{mg}, 981,2908,15.59$, and 3.19, respectively). However electrical conductivity was significantly highest in control $(0.733$ $\left.\mathrm{dSm}^{-1}\right)$. In conclusion seeds hydroprimed for 24 hours were found to be ideal for obtaining better seed quality parameters.

\section{References}

Abebe, S., 2014, Effect of hydro and osmo priming on quality of chickpea (Cicer arietinum L.) seeds. Int. J. $\mathrm{Pl}$. Breeding and Crop Sci., 1(2): 028037.

Habib, M., 2010, Sugarbeet (Beta vulgaris L.) seed pre-treatment with water and $\mathrm{HCl}$ to improve germination. African Journal of Biotechnology, 9(9): 13381342.

Heydecker, W., Chetram, R. S. and Heydecker, J. C., 1971, Water Relations of Beetroot Seed Germination II: Effects of the Ovary Cap and of the Endogenous Inhibitors. Annals of Botany, 35(139): 31-42.

Heydecker, W., Higgins, J. and Urner, Y. J., 1967, Invigoration of seeds. Seed 
Science and Technology, 3: 881-888.

Kamithi, K. D., Wachira, F. and Kibe, A., 2016, Effects of different priming methods and priming durations on enzyme activities in germinating chickpea (Cicer arietinum L.). American J. Natural and Applied Sci., 1: $1-9$.

Kaur, S., Gupta, A. K. and Kaur, N., 2013, Priming of chickpea seeds with water and mannitol overcomes the effect of salt stress on seedling growth. ICPN., 10: 18-19.

Kazem, M. I. and Tadash, I., 1997, The effects of ethanol on the germination of seeds of japonica and Indica rice (Oryza sativa L.) under Anaerobic and Aerobic conditions. Annals Bot., 79: 391-395.

Khan, A., Khalil, S. K., Khan, S. and Afzal, A., 2005, Priming effects on crop stand of turnip. Sarhad J. Agric., 21: $535-538$.

Krishnakumary, K., Venkatasubramaniam, A. and Mini, C., 2008, Optimization of hydropriming techniques for sugarbeet seed invigouration. Seed Res., 36(1): 33-36.

Mohsen, J., Adel, B., Reza, A. S. and Naser, S., 2013, Impact of pre-sowing seed treatments and fertilizers on growth and yield of chickpea (Cicer arietinum
L.) under rainfed conditions. Natura Montenegrina Podgorica, 12(1): 217229.

Orzeszko-Rywka, A. and Podlaski, S., 2003, The effect of sugar beet seed treatments on their vigour. Plant Soil Environ., 49(6): 249-254.

Perry, D. A. and Harrison, 1976, Seed vigour and seedling establishment. In J.R. Thompson (eds.) - Advances in Research and Technology of Seeds. Centre for Agricultural publishing and documentation, Wageningen. Pp. 2: 62-85.

Rashid, A., Harris, D., Hollington, D. A. and Rafiq, M., 2004, Improving the yield of spinach (Spinacia olaracea L.) in the North West Frontier Province of Pakistan using on farm seed priming. Exp. Agric., 40: 233-244.

Tiwari, T. N., Dipti, K., Rajiv, K. S. and Rajendra, P. S., 2014, Relative efficacy of seed priming with potassium nitrate and tap water in relation to germination, invigoration, growth, nitrate assimilation and yield of amaranthus.. Ann. Agri. Res. New Series, 35(2): 164-170.

Varier, A., Vari, K., A. and Dadlani, M., 2010, The subcellular basis of seed priming. Current Sci., 99: 450-456.

\section{How to cite this article:}

Kulsumbi, A. K., I. M. Sangeeta, N. M. Shakuntala, S. N. Vasudevan and Kisan, B. 2020. Standardization of Hydropriming Duration and its Effect on Physiological Parameters of Spinach (Spinacea oleracea L.). Int.J.Curr.Microbiol.App.Sci. 9(08): 1745-1750. doi: https://doi.org/10.20546/ijcmas.2020.908.201 